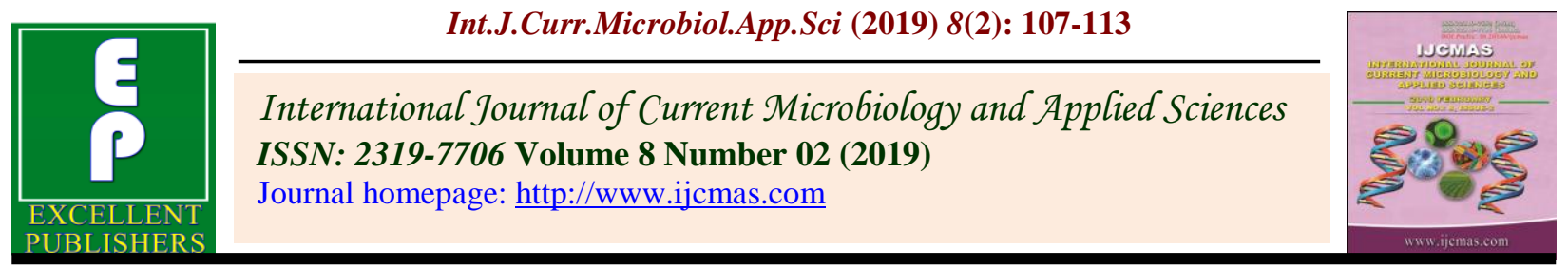

Original Research Article

https://doi.org/10.20546/ijcmas.2019.802.013

\title{
Factors Responsible for Adoption of Gobindabhog Rice in Some Selected Areas of Burdwan District, West Bengal, India
}

\section{Chowdhury Nazmul Haque*, Dinesh Das Kaibartya and Arup Kumar Bandyopadhyay}

\author{
Department of Agricultural Extension, Bidhan Chandra KrishiViswavidyalaya, \\ Mohanpur, Nadia, West Bengal, India \\ *Corresponding author
}

\begin{tabular}{|l|}
\hline Ke y w o r d s \\
$\begin{array}{l}\text { Adoption, Aromatic } \\
\text { rice, Gobindabhog }\end{array}$ \\
\hline Article Info \\
\hline $\begin{array}{l}\text { Accepted: } \\
\text { 04 January } 2019 \\
\text { Available Online: } \\
\text { 10 February } 2019\end{array}$ \\
\hline \hline
\end{tabular}

\section{A B S T R A C T}

\begin{abstract}
Adoption is a process of making a decision about an innovation of technology option offered to anyone. Even though we have brought about green revolution and moving for second green revolution, more than $60 \%$ of technology cannot reach the domain of farmer's innovation decision. So the present study takes care of adoption process of 'Gobindabhog' famous traditional aromatic rice, to explore the process and complexity of its adoption and subsequent socialization. Aromatic rice like Gobindabhog has got social, ecological and economic importance. The general objective is estimating the factors responsible for adoption of Gobindabhog rice and following are the specific objectives: -1 . To find out the relationship of the selected independent variables with the adoption behaviour of the farmers engaged in 'Gobindabhog' rice cultivation. 2. To identify the degree to which the adoption behaviour may be predicted from this characteristics. 3 . To access the different problems faced by the farmers hindering the adoption process and the measures suggested by them as remedies. The important relevation of the study depicts that the following independent variables i.e. Age $\left(X_{1}\right)$, Caste $\left(X_{2}\right)$, Family type $\left(X_{3}\right)$, Family size $\left(\mathrm{X}_{4}\right)$, Education $\left(\mathrm{X}_{5}\right)$ Area under 'Gobindabhog' rice cultivation $\left(\mathrm{X}_{6}\right)$, Land $\left(X_{7}\right)$, House $\left(X_{8}\right)$, Farm power $\left(X_{9}\right)$, Material possession $\left(X_{10}\right)$, Annual Income (X11), Social Participation $\left(X_{12}\right)$, Attitude towards 'Gobindabhog' rice cultivation $\left(X_{13}\right)$, Knowledge about 'Gobindabhog' Rice cultivation $\left(\mathrm{X}_{14}\right)$, Market Orientation $\left(\mathrm{X}_{15}\right)$, Production Orientation $\left(\mathrm{X}_{16}\right)$, Risk Orientation $\left(\mathrm{X}_{17}\right)$, Economic Motivation $\left(\mathrm{X}_{18}\right)$, Innovation Proneness $\left(\mathrm{X}_{19}\right)$, Massmedia exposure $\left(\mathrm{X}_{20}\right)$, Personal Cosmopolite $\left(\mathrm{X}_{21}\right)$, Personal Localite $\left(\mathrm{X}_{22}\right)$ have got distinct contribution to the dependent variable i.e. Adoption of Gobindabhog rice cultivation. Analyzing the data using the statistical tools correlation of coefficient and multiple regression documented results were obtained.
\end{abstract}

\section{Introduction}

Rice is a major food commodity throughout the world. Different cultures have preference for different types of rice. Scented rice or aromatic rice is popular in Asia and has gained wider acceptance in Europe and the United States. Because of their aroma, flavour and texture, aromatic varieties command a higher price in the rice market than do the non-aromatic rice varieties. Scented or aromatic rice are nature's gift to the Indian 
sub-continent and human kind at large. Compared to other classes of rice aromatic rice is highly demanded and get better premium in global market due to its pleasant aroma, superfine long slender grains with delicate curvature, remarkable linear elongation and excellent flaky soft texture on cooking. With the growing demand for these 3 quality rice in international market, high emphasis has been placed for the improvement of basmati types. The longgrained basmati rice generally exported and has assured markets, while the small and medium grained aromatic rice being regarded as a separate class of non-basmati aromatic rice has limited popularity. These indigenous varieties blessed with some of the outstanding qualities like very strong aroma, kernel elongation after cooking, fluffiness and taste and are quite popular in their native areas of cultivation and possess a domestic market value.

In West Bengal situation paddy is the main principle crop where all the farmers are habituated with paddy cultivation not only for their family consumption but also for commercial purpose. They are cultivating both traditional and high yielding variety on a commercial basis. Low-yielding aromatic rices have been the major casualty of green revolution where the main emphasis was on yield rather than quality. A large number of aromatic rices have already been lost and many are at the verge of extinction. It is more true for the small and medium-grained aromatic rices which are mostly cultivated for home consumption than the long-grained Basmati types which form the bulk of rice export. Some of the small and mediumgrained aromatic rices possess excellent aroma and other quality traits like kernel elongation after cooking, taste etc. These could be excellent sources for improving quality in high yielding varieties. Therefore, there is a strong need to conserve whatever aromatic rice germplasm is left. Although the production of aromatic rice per unit area is lower than the ordinary rice but the farmers are getting more price than ordinary rice and there is assured market of their produce in the state, only for this reason the farmers are showing interest regarding the cultivation of aromatic rice and the area under aromatic rice is increasing day by day. The 'Gobindabhog' rice is a very special cultivar from West Bengal, it is a short grain with white aromatic rice that is used for any special occasion or to offer 'Bhog' to the deity. Many traditional Bengali dishes are prepared with this aromatic Gobindabhog rice. Bengalis are connected with Gobindabhog rice forever, it is their birthright to find Gobindabhog rice and make any kind of dishes, any time they want.

The Government of West Bengal has created a great opportunity for the rice lovers, to find their favorite rice delivered right at their doorstep all over the world. The Bengalis as well as the non-Bengalis can now obtain the pleasure of having Gobindabhog rice recipies like; Bengali khichuri, Payesh (a sweet dish), Pulao and many more.Gobindabhog rice was generally being cultivated in Bardhaman, Hoogly, Nadia and Bhirbhum but now it has been intensifying into various other states in India. The rice cultivation is also one of the major job opportunity in India as well.

The Gobindabhog rice cultivation played a major role in the agricultural market. The whole rice-growing industry was changed and got a lot of popularity over the world. Every Bengali has an irresistible taste and flavor for Gobindabhog rice and no one can go wrong with it. One of the main features of Gobindabhog rice is that, it can go amazingly well with anything, and also it can be prepared by just mixing with any kind of spices. This brilliant form of rice is most popular Bengali dish, and conjures happy thoughts among people. 


\section{Materials and Methods}

Two blocks under the subdivision of BurdwanSadar South, Burdwan District of West Bengal namely Khandaghosh (consists of 10 gram panchayats) and Raina-1 (consists of 8 gram panchayats) were purposively selected for the study. From these two blocks one gram panchayat from each block was then purposively selected (where Gobindabhog rice cultivation is highly adopted) namely Lodna (Khandaghosh block) and Nadugram (Raina-1 block). And finally from this two gram panchayats one village from each i.e. Barishali (Lodna Gram Panchayat) and Nandal (Nadugram Gram Panchayat) were selected. From these two villages 50 (25 from each) Gobindabhog rice growers, who were cultivating Gobindabhog rice in their own field or having tenancy status were finally selected purposively as respondents for the study.

Adoption behaviour of Gobindabhogrice grower was considered as dependent variable and other variables were categorised in three different factors namely socio-economic factor which includes the variable age, caste, family type, family size, education, area under cultivation, land holding, house type, farm power, material possession, sociopsychological factor includes the variable annual income, social participation, attitude towards aromatic rice cultivation, knowledge level, market orientation, production orientation, risk orientation, economic motivation, innovation proneness and extension communication factor includes the variable mass media exposure, personal cosmopolite and personal localite were taken as independent variables in this study.

Data were collected by interviewing the respondents personally with the help of a well-structured pre-tested interview schedule. Correlation co-efficient analysis and multiple regression analysis were applied for interpretation of the result.

\section{Results and Discussion}

Table 1 represent the correlation co-efficient between the dependent variable adoption of 'Gobindabhog' rice cultivation and 22 other independent variables.

According to the simple correlation i.e. Pearson correlation it was found that the variables except caste $\left(\mathrm{X}_{2}\right)$, family type $\left(\mathrm{X}_{3}\right)$, family size $\left(X_{4}\right)$, farm power $\left(X_{9}\right)$, material possession $\left(\mathrm{X}_{10}\right)$, social participation $\left(\mathrm{X}_{12}\right)$, knowledge level $\left(\mathrm{X}_{14}\right)$, production orientation $\left(\mathrm{X}_{16}\right)$, innovation proneness $\left(\mathrm{X}_{19}\right)$, the other 13 independent variables had been found significant relationship with the dependent variable i.e. adoption of 'Gobindabhog' rice. These 9 independent variables had not any significant correlation with the dependent variable.

In this analysis it was found that the age $\left(\mathrm{X}_{1}\right)$ of the respondent was negatively significant at 0.05 level of probability with the adoption behaviour of the Gobindabhog rice growers. This indicates that the younger generation of the farmers was interested in growing Gobindabhog rice in their field more than the older farmers.

The independent variable market orientation $\left(\mathrm{X}_{15}\right)$ was positively significant at 0.05 level of probability with the adoption behaviour i.e. person with higher market orientation are interested in adoption of Gobindabhog rice.

The independent variables education $\left(\mathrm{X}_{5}\right)$ and house type $\left(\mathrm{X}_{8}\right)$ were positively significant at 0.05 level.

The other 9 independent variables i.e. area under aromatic rice cultivation $\left(\mathrm{X}_{6}\right)$, land 
$\left(\mathrm{X}_{7}\right)$, annual income $\left(\mathrm{X}_{11}\right)$, attitude towards 'Gobindabhog' rice cultivation $\left(\mathrm{X}_{13}\right)$, risk orientation $\left(\mathrm{X}_{17}\right)$, economic motivation $\left(\mathrm{X}_{18}\right)$, mass media exposure (X20), personal cosmopolite $\left(\mathrm{X}_{21}\right)$, personal localite $\left(\mathrm{X}_{22}\right)$ was positively significant at 0.01 level of probability with the adoption behaviour of Gobindabhog rice growers. Thus it can be inferred that the respondents with higher degree of these variables are more interested in adoption of Gobindabhog rice in their field situation.

According to Spearman correlation it was found that the variables except caste $\left(X_{2}\right)$,family type $\left(X_{3}\right)$, family $\operatorname{size}\left(X_{4}\right)$ farm power $\left(\mathrm{X}_{9}\right)$, material possession $\left(\mathrm{X}_{10}\right)$, social participation $\left(\mathrm{X}_{12}\right)$ knowledge level of farmer $\left(\mathrm{X}_{14}\right)$, production orientation $\left(\mathrm{X}_{16}\right)$, innovation proneness $\left(\mathrm{X}_{19}\right)$, the other 13 independent variables have recorded significant relationship with the dependent variable adoption of Gobindabhog rice. These 9 independent variables had not any significant correlation with the dependent variable.

So it was found the mass media exposure, the personal cosmopolite and personal localite is positively significant with the adoption.

Social participation is one of the important factors which help the farmer to adopt the modern practices. Generally the farmers having more social participation is likely to have higher adoption rate but in our study we found that there was no significant relationship with the dependent variable i.e. adoption of Gobindabhog rice that means the farmers who have adopted rice production technology in the 2 villages they were only maintaining relationship with some experts.

It was also found that caste was not significant to the adoption of Gobindabhog variety of rice. It may be assumed that from the recent diffusion innovation studies caste was not important factors for adoption of any technology.

The variables land holding, annual income, area under Gobindabhog rice cultivation which is the characteristics of one's sociopersonal dimension went positively significant with the adoption behaviour of the cultivars. These are the indicators of social prestige, esteem and status of an individual in the social system.

It was revealed in the study from the results that attitude towards Gobindabhog rice cultivation, market orientation $\left(\mathrm{X}_{15}\right)$, risk orientation, economic motivation $\left(\mathrm{X}_{18}\right)$ were variables of socio-psychological dimension which had gone together to build up a strong entrepreneurial motivation, which in turns steer the respondents for adoption of Gobindabhog rice at a substantial level. These variables have further established themselves to be positively and significantly correlated.

Table 2 represents the step wise multiple regression between the dependent variable adoption of Gobindabhog rice cultivation and the other 22 independent variables. In this table the unstandardized regression coefficient (' $b$ ' value), the standard error of $b$ ( $\mathrm{SE}$ of $\mathrm{b}$ ), the standardized partial regression co-efficient ( $\beta$ value), ' $t$ ' values, the standard error of intercept, the co-efficient multiple regression determination $\left(\mathrm{R}^{2}\right)$ and the adjacent $\mathrm{R}^{2}$ values are presented.

It was found that the independent variables Area under cultivation $\left(\mathrm{X}_{6}\right)$, Age $\left(\mathrm{X}_{1}\right)$ and Economic motivation $\left(\mathrm{X}_{18}\right)$ had been retained after eliminating the other trivial variables in the preceding steps.

The table depicted that the variable Area under cultivation $\left(\mathrm{X}_{6}\right)$ recorded highest regression effect on the extent of adoption 
having the $\beta$ value of 0.588 . Thus it had an positive effect on the adoption level. It was also observable that a unit change in this variable had contributed 1.850 unit changes in the adoption level which is also the highest contribution of all.

The variable Economic motivation $\left(\mathrm{X}_{18}\right)$ also had a positive effect on adoption exhibiting the $\beta$ value of 0.240 . A unit change in this variable had contributed 1.169 unit changes in the adoption level. On the other hand the variable Age $\left(\mathrm{X}_{1}\right)$ recorded the regression effect on the extent of adoption having the $\beta$ value of -0.159 , thus representing a negative effect on the adoption level and with the unit change in this variable had contributed 0.159 unit changes (negatively). Here the $\mathrm{R}^{2}$ value being 0.643 , it is to infer that the 3 variables together explain $64.30 \%$ variation embedded with the predicted variable of adoption of Gobindabhog rice cultivation.

Table.1 Correlation Co-efficient between Adoption behaviour of Gobindabhog Rice cultivars and rest 22 independent variables

\begin{tabular}{|l|c|c|}
\hline Variables & $\begin{array}{c}\text { 'r' value } \\
\text { (Pearson) }\end{array}$ & \begin{tabular}{c} 
(Spearman) \\
\hline
\end{tabular} \\
\hline Age $\left(\mathrm{X}_{1}\right)$ & $-0.305^{*}$ & $-0.306^{*}$ \\
\hline Caste $\left(\mathrm{X}_{2}\right)$ & -0.135 & -0.160 \\
\hline Family type $\left(\mathrm{X}_{3}\right)$ & 0.094 & 0.095 \\
\hline Family size $\left(\mathrm{X}_{4}\right)$ & 0.031 & 0.044 \\
\hline Education $\left(\mathrm{X}_{5}\right)$ & $0.314^{*}$ & $0.321^{*}$ \\
\hline Area under cultivation $\left(\mathrm{X}_{6}\right)$ & $0.719^{* *}$ & $0.738^{* *}$ \\
\hline Land $\left(\mathrm{X}_{7}\right)$ & $0.475^{* *}$ & $0.393^{* *}$ \\
\hline House $\left(\mathrm{X}_{8}\right)$ & $0.311^{*}$ & $0.284^{*}$ \\
\hline Farm power $\left(\mathrm{X}_{9}\right)$ & 0.092 & 0.040 \\
\hline Material Possession $\left(\mathrm{X}_{10}\right)$ & 0.178 & 0.201 \\
\hline Annual Income $\left(\mathrm{X}_{11}\right)$ & $0.465^{* *}$ & $0.437^{* *}$ \\
\hline Social Participation $\left(\mathrm{X}_{12}\right)$ & 0.164 & 0.135 \\
\hline Attitude towards Gobindabhogrice & $0.486^{* *}$ & $0.547^{* *}$ \\
\hline cultivation $\left(\mathrm{X}_{13}\right)$ & & \\
\hline Knowledge Level $\left(\mathrm{X}_{14}\right)$ & 0.072 & 0.047 \\
\hline Market Orientation $\left(\mathrm{X}_{15}\right)$ & $0.317^{*}$ & $0.309^{*}$ \\
\hline Production Orientation $\left(\mathrm{X}_{16}\right)$ & 0.119 & 0.162 \\
\hline Risk Orientation $\left(\mathrm{X}_{17}\right)$ & $0.554^{* *}$ & $0.598^{* *}$ \\
\hline Economic Motivation $\left(\mathrm{X}_{18}\right)$ & $0.580^{* *}$ & $0.599^{* *}$ \\
\hline Innovation Proneness $\left(\mathrm{X}_{19}\right)$ & 0.182 & 0.127 \\
\hline Mass media exposure $\left(\mathrm{X}_{20}\right)$ & $0.473^{* *}$ & $0.474^{* *}$ \\
\hline Personal Cosmopolite $\left(\mathrm{X}_{21}\right)$ & $0.459^{* *}$ & $0.446^{* *}$ \\
\hline Personal localite $\left(\mathrm{X}_{22}\right)$ & $0.472^{* *}$ & $0.479^{* *}$ \\
\hline
\end{tabular}

Note: $* *=$ Significant at 0.01 level of probability

$*$ = Significant at 0.05 level of probability. 
Table.2 Multiple Regression analysis (By Stepwise Method of Multiple Regression Equation) of the Adoption Behaviour (Y) with the other 22 causal variables

\begin{tabular}{|c|c|c|c|c|}
\hline \multirow{3}{*}{ Variables } & \multirow{2}{*}{\multicolumn{2}{|c|}{$\begin{array}{c}\text { Unstandardized } \\
\text { Co-efficient }\end{array}$}} & \multirow{2}{*}{\multicolumn{2}{|c|}{$\begin{array}{c}\text { Standardized } \\
\text { Co-efficient }\end{array}$}} \\
\hline & & & & \\
\hline & \multirow{2}{*}{$\begin{array}{c}\text { 'b' } \\
\text { value }\end{array}$} & \multirow[t]{2}{*}{ Standard } & \multirow[t]{2}{*}{$\beta$} & \multirow{2}{*}{$\begin{array}{l}\text { 't' } \\
\text { value }\end{array}$} \\
\hline & & & & \\
\hline & & error of & & \\
\hline & & 'b' & & \\
\hline \multicolumn{5}{|l|}{ Adoption (Y) } \\
\hline (constant) & 57.611 & 4.170 & & 13.816 \\
\hline \multicolumn{5}{|l|}{ Area under } \\
\hline cultivation $\left(\mathbf{X}_{6}\right)$ & 1.850 & 0.325 & 0.588 & $5.687 * *$ \\
\hline Age $\left(X_{1}\right)$ & \multirow[t]{2}{*}{-0.159} & \multirow[t]{2}{*}{0.054} & \multirow[t]{2}{*}{-0.263} & \multirow{2}{*}{$2.960 * *$} \\
\hline & & & & \\
\hline $\begin{array}{l}\text { Economic } \\
\text { motivation }\left(\mathbf{X}_{18}\right)\end{array}$ & 1.169 & 0.507 & 0.240 & $2.307^{*}$ \\
\hline & & & & \\
\hline & & & & \\
\hline & & & & \\
\hline
\end{tabular}

Standard Error of intercept $=3.238 ; R=0.802 ; R^{2}=0.643 ;$ Adjacent $R^{2}=0.619$

Note: $* *=$ Significant at 0.01 level of probability

$*$ = Significant at 0.05 level of probability

Adoption process is a complex, multifaceted and polymorphous while we keep on contemplating its qualitative expansion through the domain of behavioural disposition, especially for the farming community. The expression of effectional discourses that is attitude and motivation has been attuned to a complex parametric disposition consisting of resources, institution, organization, market etc. The other non-parametric disposition has been the discrete psychological deposition and its acquisition to technology adoption the key content of the study. The present study has been resultants through an estimation of variable interaction and its factorial configuration. It can be concluded from the study that Area under cultivation $\left(\mathrm{X}_{6}\right)$ as a resource is still a unique characteristic to impact on adoption process. Economic motivation, as a tiny social echelon has characterised the process of adopting aromatic rice Age has been catalytic and characteristic with the process of adoption especially in 'Gobindabhog' rice. Any adoption process is basically a heterophylic exposition of socio economic and technological interaction which has wellbeing networked in the given study. The adoption process as studies under this heuristic research has been not that unique so far to estimate the process as unique with Gobindabhog rice. So scopes are there to identify and elucidate whether adoption process of Gobindabhog rice can present a unique process over the gross generalization occurring in the general adoption behaviour. 


\section{References}

Adhikari, B., Bhowmick, M.K. and Bhadra, K.K. 2013. Sugandhi dhanerchas, adhik laver aswas (in Bengali). Saar Samachar, 51: 22-28.

Adhikari, B., Bhowmick, M.K., Halder, A. and De, S. 2011 . Paschimbangeamanmorsumeysugandhi dhanerchas (in Bengali). Saar Samachar, 49: 33-39.

Anonymous 2012. Promotion of Bengal aromatic rice through improved production and processing system. In. $B C K V$ Newsletter (Ed. Brahmachari, K.), Bidhan Chandra Krishi Viswavidyalaya, West Bengal, 6: 2.

Ghoshal, R., Garai, S. and Mazumder, G. 2010.Adoption of improved fish cultivation practices among the fish farmers of Uttar Dinajpur district of West Bengal. Env. Eco., 28: 2104-06.

Mehta, B.M. and Sonawane, M. 2012. Entrepreneurial behaviour of mango growers of Valsad District of Gujarat state. Indian Res. J. Extn. Edu., 12: 7882.

Mote, T.S. and Wadnerkar, D.W. 2009.A study on knowledge and adoption of soybean production technology among the farmers in Hingoli district of Maharashtra. Agric. Update., 4: 229-32.

Sharma, K.C., Singh, P. and Panwar, P. 2012.Association of personal attributes with knowledge and adoption regarding maize production in Bhilwara
Rajasthan. Agric. Update., 7: 376-80.

Thawait, D., Kar, S. and Patel, A.K. 2014. Agronomic evaluation of scented rice (Oryza sativa L.) under different planting patterns. J. Crop Weed, 10:175-78.

Adhikari et al., 2011 At present, only 12-15 indigenous aromatic rice varieties (IARVs) are being cultivated in some scattered pockets of different districts in West Bengal in an unorganized manner

Deb (2005) in his famous book, entitled, "Seeds of Tradition, Seeds of Future" provided detailed morphological descriptions of 416 Indian indigenous rice varieties

Ghosh et al., (1995) stated that The local variety Gobindabhog, with small, fine, scented grain, was improved by induction of semidwarf mutants

Hasib et al., (2004) postulated three induced mutants of local aromatic tall indica cultivars Tulaipanja (IET 14142 and IET 14143) and Gobindabhog (IET* IET *13541) were crossed with 2 Basmati cultivars (Basmati 370 and Pakistan Basmati) to develop highyielding cultivars with Basmati-type grain quality suitable for cultivation in eastern India

Kole (2005) Sated in Journal-of-Geneticsand-Breeding that Inheritance of plant height in five gamma -ray induced mutants of aromatic rice cultivar 'Gobindabhog' was studied through 6x6 diallele cross and segregation analyses.

\section{How to cite this article:}

Chowdhury Nazmul Haque, Dinesh Das Kaibartya and Arup Kumar Bandyopadhyay. 2019. Factors Responsible for Adoption of Gobindabhog Rice in Some Selected Areas of Burdwan District, West Bengal, India. Int.J.Curr.Microbiol.App.Sci. 8(02): 107-113. doi: https://doi.org/10.20546/ijcmas.2019.802.013 